\title{
Understanding and Control of Biopolymer Fouling in Ultrafiltration of Different Water Types
}

\author{
Xing Zheng ${ }^{1,2, *}$, Frederik Zietzschmann ${ }^{2}$, Stephan Plume ${ }^{2}$, Hendrik Paar ${ }^{2}$, Mathias Ernst ${ }^{3}$, \\ Zi Wang ${ }^{4}$ and Martin Jekel ${ }^{2, *}$ \\ 1 State Key Laboratory Base of Eco-Hydraulic Engineering in Arid Area, Xi'an University of Technology, \\ Xi'an 710048, China \\ 2 Department of Water Quality Control, Technical University of Berlin, Berlin 10623, Germany; \\ Frederik.Zietzschmann@tu-berlin.de (F.Z.); Stephan.Plume@tzw.de (S.P.); \\ Hendrik.Paar@senstadtum.berlin.de (H.P.) \\ 3 Department of water resource and water supply, Technical University Hamburg-Hamburg, Hamburg 21073, \\ Germany; mathias.ernst@tuhh.de \\ 4 National Supervision \& Inspection Center of Environmental Protection Equipment Qaulity (Jiangsu), \\ Yixing 214205, China; wangziyixing@163.com \\ * Correspondence: zhengxingde@yahoo.de (X.Z.); Martin.Jekel@tu-berlin.de (M.J.); \\ Tel.: +86-29-8231-2906 (X.Z.); +49-30-314-23339 (M.J.)
}

Academic Editor: Sunny Jiang

Received: 10 March 2017; Accepted: 20 April 2017; Published: 23 April 2017

\begin{abstract}
The present work focuses on understanding and control of biopolymer fouling in ultrafiltration of a typical surface water and nearby secondary effluent for direct and indirect portable use. Characterization results show that both kinds of biopolymers are of similar molecular weight. Longer than one year water quality monitoring results show that the $\mathrm{C} / \mathrm{N}$ ratio in the secondary effluent biopolymers was relatively constant at around 4.8 , while that in the surface water macromolecules fluctuated at around 6.9. Under a similar mass load, the investigated secondary effluent biopolymers lead to hydraulic resistance slightly higher than that caused by filtering surface water macromolecules; however, the correspondingly formed fouling is significantly less reversible by hydraulic backwashing. The quantity of the nitrogenous biopolymers in the secondary effluent demonstrated a strong correlation with the extent of the irreversible fouling in ultrafiltration (UF), while that from the surface water did not. In membrane fouling cleaning tests, certain detergent demonstrated high efficiency in removing the irreversible fouling after UF of the secondary effluent, but presented no effect in eliminating fouling caused by the surface water foulants. In-line coagulation using $\mathrm{FeCl}_{3}$ prior to UF was shown as an effective fouling control method, but the effect depends heavily on the type of feed water.
\end{abstract}

Keywords: biopolymer fouling; protein; secondary effluent; surface water; ultrafiltration

\section{Introduction}

Ultrafiltration (UF) membranes have often been used in filtering surface water or treated domestic wastewater for direct and indirect portable use, e.g., as pretreatment prior to RO (Reverse Osmosis) in water purification or reclamation. Nevertheless, the economic feasibility of UF is restricted by fouling phenomena to a large extent. To select suitable fouling control strategies such as pre-treatment, chemical cleaning, etc., identification and characterization of primary foulants is necessarily required [1].

Previous studies show that biopolymers (macromolecular protein-like substances and polysaccharides) are primary organic foulants in low pressure membrane filtration of both secondary effluent (SE) $[2,3]$ and surface water (SW) [4,5]. SE biopolymers are the macromolecular fraction of 
effluent organic matter (EfOM). They are mostly solvable microbiological products (SMP) secreted by microorganisms during metabolism and/or related to extracellular polymeric substances (EPS) [6-8]. Using advanced characterization technologies, the presence of proteins and polysaccharides in this fraction are clearly identified [2]. Quantitatively, it is suggested that in the macromolecular fraction increased content of protein-like substances over polysaccharides would lead to more irreversible membrane fouling [9]. This is evident when model substances are tested in membrane processes [10]. In UF of real SE, Haberkamp et al. [11] demonstrated the important contribution of protein-like material on irreversible fouling as well. Nevertheless, it was not clarified if the protein-like substances are from biopolymer fraction or from other fractions with smaller molecular sizes. Considering complicated synergistic effect of different organics in feed water $[2,12]$ and limited representation capacity of model substances in fouling studies [13], quantitatively reliable results identifying the role of protein-like substances in real biopolymer fouling need to be demonstrated.

In low-pressure membrane filtration of surface water, the discussion about the contribution of protein-like substances to membrane fouling exists as well. For instance, in a UF of SW study, no clear relationship between the carbon content of biopolymers and UF fouling was observed [5]. Instead, the presence of protein-like substances in water, regardless of their molecular weight, seems to contribute to irreversible fouling more significantly. Nevertheless, Kimura et al. [4] quantified biopolymer content in different surface waters using liquid chromatography with organic carbon and $\mathrm{UV}_{254}$ (LC-OCD-UVD) detectors, and observed that the quantity of biopolymers (in terms of organic carbon) is well related to fouling development in microfiltration (MF) processes, without considering the presence of protein-like substances at all.

The above-mentioned studies suggest that in both SE and SW the contribution of protein-like substance in biopolymer fraction to membrane fouling needs to be evaluated in more detail. One way to gain more insights is to compare the severity of biopolymer fouling in UF of both types of water, and then evaluate its relation with the content of protein-like substances. This process is feasible because protein content in biopolymers originating from SE and SW is quantitatively quite different. For instance, some investigations on the EfOM biopolymers show that this fraction contains relatively high protein-like material, indicated by the ratio of carbon to nitrogen ( $\mathrm{C}: \mathrm{N}$ ratio) in the range of $6.2 \pm 1.7$ [7]. This C:N ratio indicator is consistent with the Redfield ratio (C:N:P = 106:16:1) [14]. In comparison, biopolymers from SW predominantly consist of polysaccharides from more diverse sources, such as phytoplankton, algae and terrigenous [15]. They exhibit a significantly higher C:N ratio over the Redfield ratio [16]. Although polysaccharides from these two typical water types can be different in terms of contributing to fouling [17], they are considered to have significantly lower fouling potential than protein-like substances $[10,18]$. Nevertheless, there is a lack of information distinguishing the difference between these two kinds of organics on fouling. Thus, the comparison of these biopolymers is expected to indicate a clear difference in fouling severity.

The comparison of UF fouling in treating SE and SW was conducted in some previous studies $[19,20]$. These pioneer works clearly revealed significant differences in UF fouling during filtration of EfOM and SW biopolymers. However, the uncertainty of corresponding conclusions rises when the following conditions are considered. For instance, the results can be affected due to the change of operational conditions such as selection of backwash water. In UF fouling studies the water chemistry of backwash water needs to be consistent with the feed water because, in most UF systems, the permeate is used for backwash. When other kinds of water (e.g., when demineralized water is used for backwash [21]) are used instead, the reversibility of fouling can be altered dramatically, which will affect the conclusion obtained using permeate for hydraulic back flush. Secondly, the represent ability of water samples needs to be considered seriously because fluctuation of water quality always challenges the conclusion made based on very limited number of samples [20]. At this point, long term testing and frequent monitoring are necessary to get statistically reliable results. In addition, previous works are mostly lab scale investigations $[19,20]$. While the results no doubt reflect the fouling 
potential of feed water, pilot scale investigations are more preferred to confirm lab scale results and deliver practically applicable knowledge [22].

In the present work, lab-scale UF tests were conducted to identify fouling potential of biopolymers from typical SE and SW sources with a monitoring period longer than one year. LC-OCD-OND was used to quantify the carbon and nitrogen content in the biopolymer fraction and indicate the content of protein-like substances. The filterability and reversibility of biopolymer fouling were evaluated and their relation with the carbon and nitrogen content in the biopolymer fraction was identified. Furthermore, pilot scale UF with chemical cleaning was performed to gain insight into the chemical property of the irreversible fouling. In the end in-line coagulation tests were conducted for several months to illustrate the difference of UF performance in treating SE and SW containing biopolymers with very different characteristics.

\section{Materials and Methods}

\subsection{Secondary Effluent}

Treated domestic wastewater used in the present work is the SE from the wastewater treatment plant (WWTP) Ruhleben in Berlin with a treatment capacity of $250,000 \mathrm{~m}^{3} / \mathrm{d}$. The wastewater treatment process includes a conventional activated sludge process and biological phosphorus and nitrogen removal. Inorganic coagulant $\left(\mathrm{FeCl}_{3}\right)$ was added in the biological process to keep total phosphorus concentrations below $0.5 \mathrm{mg} / \mathrm{L}$. The effluent from the secondary clarifier was used as feed water directly to the pilot UF after a pre-filter with a pore size of $100 \mu \mathrm{m}$, and for the lab-scale UF test after pre-filtration using cellulose nitrate filter with a pore size of $0.45 \mu \mathrm{m}$ (Satorious). More detailed information about the plant can be found in previous studies [23].

\subsection{Surface Water}

SW samples were taken from the Landwehrkanal, Berlin. This SW canal is connected with the upper and lower part of Spree River and flows through Berlin City. The sampling site was located behind a small barrage, providing good mixture of the canal water. Prior to the UF pilot plant, a sieve filter with a pore size of $200 \mu \mathrm{m}$ was used to treat the SW. River water used for the lab-scale UF test was prefiltered using a cellulose nitrate filter with a pore size of $0.45 \mu \mathrm{m}$ (Satorious). More information about this water can be found in Tian's work [19].

\subsection{Lab Scale UF Test}

Lab scale dead-end flat-sheet filtration tests using Amicon UF cell (UF membrane NADIR@ UP150 with MWCO $150 \mathrm{k} \mathrm{Da}$, Wiesbaden, Germany) were performed to conduct membrane filtration experiments. For each test a new UF membrane was used. Using this setup filterability and reversibility of water sample can be quantified. Here, filterability is defined as the hydraulic resistance caused by fouling after initial filtering of a $500 \mathrm{~mL}$ water sample. Reversibility refers to the hydraulically irreversible resistance after a number of filtration and backwash cycles. This kind of test has been well established and accepted in previous studies [24]. In brief, each test was conducted in five filtration cycles using a filtration cell with a volume of $200 \mathrm{~mL}$ (Amicon 8200, Millipore, Billerica, MA, USA) and an effective membrane filtration area of $28.7 \mathrm{~cm}^{2}$. During each single filtration cycle, a $500 \mathrm{~mL}$ water sample (pre-filtered using a cellulose nitrate filter with a pore size of $0.45 \mathrm{~mm}$ (Sartorius)) is supplied to the cell through a connected feed tank $(4 \mathrm{~L})$ in dead-end mode under constant pressure at one bar. The membrane is backwashed using a $50 \mathrm{~mL}$ salt solution $\left(\mathrm{CaCl}_{2} 2.8 \mathrm{mmol} / \mathrm{L}, \mathrm{NaCl} 5.4 \mathrm{mmol} / \mathrm{L}\right.$ dissolved in pure water, conductivity around $1200 \mu \mathrm{S} / \mathrm{cm}$ to simulate UF permeate treating SE) after producing $500 \mathrm{~mL}$ permeate. Then, pure water flux was determined by filtering $200 \mathrm{~mL}$ pure water through the fouled membrane. The corresponding hydraulic resistance can be calculated according to the Darcy equation. In either filtration or backwash, the water is pressurized using nitrogen under 1 bar. The operation is conducted at room temperature $\left(22^{\circ} \mathrm{C}\right)$ and at a stirring speed of $120 \mathrm{rpm}$. 
It should be mentioned that, although the situation of the lab scale test is different to that in the pilot test (e.g., operational mode constant pressure vs. constant flux, membrane type flat sheet vs. hollow fiber membrane, pre-filter mesh size $0.45 \mu \mathrm{m}$ vs. 100/200 $\mu \mathrm{m}$ ), they confirm the difference in fouling potential of different water samples [24]. This implies that the results from these two tests are consistent with each other regarding the fouling nature of feed water and the order of fouling severity. Therefore, the lab test results are reliable in comparing fouling effect of various feed waters.

\subsection{Pilot Scale UF (without In-Line Coagulation) and Cleaning in Place (CIP) Test}

Pilot scale investigations were carried out using a dead-end pressure driven UF pilot plant with hydrophilized PES membranes (hollow fibre membrane, Dizzer 450, Inge AG, Inge, Greifenberg, Germany) after a pre-filter (100 $\mu \mathrm{m}$ mesh size) with no coagulant was used. Detailed information about the membrane can be found in a previous study [23]. In the present work, the UF unit was operated in dead-end filtration mode at a constant flux of $60 \mathrm{~L} /\left(\mathrm{m}^{2} \cdot \mathrm{h}\right)$. According to preliminary tests the difference of trans-membrane pressure (TMP) increase rate with and without in-line coagulation was distinct under such flux and the increase rates in filtering both types of water under different coagulant dosages were in a reasonable range [23]. Therefore, the flux was fixed at $60 \mathrm{~L} /\left(\mathrm{m}^{2} \cdot \mathrm{h}\right)$ during all pilot scale tests. The basic operational condition is as follows: after 20 min filtration the membrane was backwashed for $25 \mathrm{~s}$ using permeate water at a flux of $260 \mathrm{~L} /\left(\mathrm{m}^{2} \cdot \mathrm{h}\right)$. An experiment ended when the TMP reached 600 mbar. The time the plant operated from the start until TMP reached $600 \mathrm{mbar}$ is termed as the operating duration (in days). After each pilot experiment the fouled membrane was chemically cleaned (CIP) in a two-step process: In CIP I the fouled membrane was soaked in a base solution ( $\mathrm{pH} 12$ by dissolving $\mathrm{NaOH}$ in demineralized water) for $30 \mathrm{~min}$ at a temperature around $20{ }^{\circ} \mathrm{C}$. After the module was flushed using tap water, the permeability was measured by filtering tap water for at least $10 \mathrm{~min}$ to get a stable value. In CIP II, different reagents were used to soak the module for $60 \mathrm{~min}$ at $20^{\circ} \mathrm{C}$. The reagents include protease type XXIII $50 \mathrm{mg} / \mathrm{L}$ at pH 7 (Sigma Aldrich, St. Louis, MO, USA), $\alpha$-amylase $50 \mathrm{mg} / \mathrm{L}$ at pH 7 (Sigma Aldrich), $\mathrm{H}_{2} \mathrm{O}_{2} 200 \mathrm{mg} / \mathrm{L}$ (Sigma Aldrich), raw ethanol (100\%, analytical grade) and diluted with pure water at $50 \%(v / v)$ and $10 \%(v / v)$ at $\mathrm{pH} 12$, and sodium dodecyl sulfate (Sigma Aldrich) at a concentration of 2 and $0.1 \mathrm{~g} / \mathrm{L}$ at pH 12 (dissolved in demineralized water). As each CIP test (including filtration and CIP I and II) was conducted within two days, scaling was assumed not to occur significantly. Therefore, no acid cleaning was conducted for these tests. The chemicals used in CIP I and II are summarized in Table 1.

Table 1. Cleaning in place (CIP) conditions in tests.

\begin{tabular}{|c|c|c|c|c|c|c|c|c|c|c|}
\hline CIP Step & Test 1 & Test 2 & Test 3 & Test 4 & Test 5 & Test 6 & Test 7 & Test 8 & Test 9 & Test 10 \\
\hline $\begin{array}{c}\text { CIP I } \\
30 \mathrm{~min} \text { at } 20^{\circ} \mathrm{C}\end{array}$ & \multicolumn{10}{|c|}{$\mathrm{NaOH}$ dissolved in demineralized water with a $\mathrm{pH} 12$} \\
\hline $\begin{array}{c}\text { CIP II } \\
60 \text { min at } 20^{\circ} \mathrm{C}\end{array}$ & $\begin{array}{l}\text { Protease } \\
50 \mathrm{mg} / \mathrm{L}\end{array}$ & $\begin{array}{l}\text { Amylase } \\
50 \mathrm{mg} / \mathrm{L}\end{array}$ & $\begin{array}{c}\mathrm{H}_{2} \mathrm{O}_{2} 200 \\
\mathrm{mg} / \mathrm{L}\end{array}$ & $\begin{array}{c}\text { Ethanol } \\
100 \%\end{array}$ & $\begin{array}{c}\text { Ethanol } \\
50 \%\end{array}$ & $\begin{array}{c}\text { Ethanol } 10 \% \text {, } \\
\text { pH } 12\end{array}$ & $\begin{array}{l}\text { SDS } 2 \mathrm{~g} / \mathrm{L} \\
\mathrm{pH} 12\end{array}$ & $\begin{array}{c}\text { SDS } 0.1 \\
\mathrm{~g} / \mathrm{L}, \mathrm{pH} 12\end{array}$ & $\begin{array}{l}\text { SDS } 2 \text { g/L } \\
\text { pH } 12\end{array}$ & $\begin{array}{c}\text { SDS } 2 \mathrm{~g} / \mathrm{L}, \\
\mathrm{pH} 12\end{array}$ \\
\hline
\end{tabular}

\subsection{Pilot UF Test with In-Line Coagulation}

In-line coagulation with UF tests were conducted using $\mathrm{FeCl}_{3}$ (CVB Albert Carl $\mathrm{GmbH}$ \& $\mathrm{Co}$ KG, Berlin, Germany) as coagulant to control fouling development in UF of SE and SW. During all experiments, $\mathrm{FeCl}_{3}$ was added after the $100 \mu \mathrm{m}$ pre-filter into the feed water without the removal of coagulated solids (in-line coagulation) prior to the UF pilot plant. The feed pump of the UF pilot was used as the mixer. The reaction time after coagulant dose until the flocs arrived on the membrane surface was kept at around $90 \mathrm{~s}$ based on preliminary tests. Basic operational conditions of the membrane system are identical to the plant without in-line coagulation. In terms of $\mathrm{Fe}^{3+}$ content, the dosage was fixed at $0.04,0.07$ or $0.15 \mathrm{mmol} / \mathrm{L}\left(2,4\right.$ and $8 \mathrm{mg} / \mathrm{L}$ of Fe${ }^{3+}$, correspondingly) during each single test treating the SE, while in UF of the SW the dosage was selected as 0.02 and $0.04 \mathrm{mmol} / \mathrm{L}$ ( 1 and $2 \mathrm{mg} / \mathrm{L}$ of $\mathrm{Fe}^{3+}$ ) based on some preliminary tests. One test is completed when TMP achieved 600 mbar. After each experiment, the module was chemically cleaned using base, oxidant and acid 
subsequently. If the permeability recovery could not achieve $90 \%$ after using different cleaning reagents, a new module was used for further experiments. Detailed test conditions can be found in a previous publication [23].

\subsection{Water Analysis}

\subsubsection{LC-OCD-UVD-OND}

The dissolved macromolecular organic compounds in both waters are quantified using liquid chromatography with online organic carbon, UV, and organic nitrogen detectors (LC-OCD-UVD-OND). The LC-OCD-UVD-OND system (DOC-LABOR Dr. Huber, Karlsruhe, Germany) was equipped with a size exclusion column HW50S (GROM Analytik HPLC GmbH, Rottenburg-Halfingen, Germany) and online dissolved organic carbon (OCD), $\mathrm{UV}_{254}$ (UVD), and dissolved organic nitrogen (OND) detectors. The liquid chromatogram (LC) unit separates organic compounds based on their molecular size and the separated compounds were detected by online detectors; larger molecular size material were generally indicated by a shorter elution time. Using ChromCALC ${ }^{\circledR}$ software (ChromCALC ${ }^{\circledR}$, DOC-LABOR Dr. Huber, KarlsruheCity, Germany), the corresponding peak area could be converted into concentrations ( $\mathrm{mg} \mathrm{C} / \mathrm{L}, \mathrm{mg} \mathrm{N} / \mathrm{L}$ ) and $\mathrm{UVA}_{254}$ absorbance $(1 / \mathrm{m})$. According to the manufacturer [25], the ratio between dissolved organic carbon (DOC) measured after the column and the DOC in bypass can be used to reflect the relative hydrophobicity of a water sample. In the present work, this ratio of different water samples is calculated and compared. The ratio of ideal hydrophilic substances is $100 \%$. A lower value indicates increased hydrophobicity.

\subsubsection{Fluorescence Excitation Emission Matrix}

Fluorescence excitation emission matrix (F-EEM, FluoroMax-4, Horiba, Kyoto, Japan) is used to characterize the feedwaters. The spectrofluorometer was equipped with a xenon excitation source. EEM were collected for excitation wavelengths from 250 to $500 \mathrm{~nm}$ in $5 \mathrm{~nm}$ steps and for emission wavelengths from 300 to $600 \mathrm{~nm}$ in $5 \mathrm{~nm}$ steps. Both excitation and emission slit bandwidths were fixed at $5 \mathrm{~nm}$. The measurement was conducted at room temperature $\left(20 \pm 0.5^{\circ} \mathrm{C}\right)$. All samples were measured at neutral $\mathrm{pH}$ and a DOC of approximately $5 \mathrm{mg} / \mathrm{L}$ to minimize inner effect [26].

\subsubsection{Other Water Quality Parameters}

In the present work, a High TOC meter (Elementar Analysensysteme GmbH, Langenselbold, Germany) was used to analyse DOC concentration. The content of humic substances in water samples was identified using $\mathrm{UV}_{254}$ absorption which was quantified using a spectrometer (Perkin Elmaer UV/VIS Spectrometer, Waltham, MA, USA) at a wavelength of $254 \mathrm{~nm}$. Turbidimeter (2100 NIS Turbidimeter, HACH, Loveland, CO, USA) was used to quantify turbidity. pH 537 (WTW, Weilheim, Germany) was used to measure $\mathrm{pH}$. The ion content of $\mathrm{Ca}$ and $\mathrm{Na}$ was identified using atomic absorption spectrometry (Analytik Jena, Jena, Germany). Most of the parameters were analyzed once or twice a week, while some parameters were measured less frequently due to less focus. Detailed number of measurements can be seen in Table 2 .

\section{Results and Discussion}

\subsection{Overview of Water Quality}

During water quality monitoring period (February 2009-August 2010, except winter 2009 for SW), these two types of water demonstrated similar $\mathrm{pH}$ and calcium content (Table 2), even during rainfall event. This indicates that the SE and SW deliver similar water chemistry condition (e.g., alkalinity), which builds up fair situation in comparing fouling because both parameters are critical factors affecting the severity of organic fouling [21,27]. Although the ion strength (reflected by conductivity) of these two types of water is different, that affects the severity of UF fouling to a minor extent 
because the difference is from the content of mono-charged ions (e.g., sodium, Table 2). Compared to multi-charged metal ions, the mono-charged species affect the severity of organic fouling to a much less extent [12,28]. With respect to the turbidity of the SE and SW after pre-filters, the average value and its fluctuation in the SE are lower than that of the SW.

Table 2. Water quality of secondary effluent (SE) and surface water (SW) during the monitoring period, number of LC-OCD measurements $>100$.

\begin{tabular}{|c|c|c|}
\hline Parameters & SE & SW \\
\hline Temperature $\left({ }^{\circ} \mathrm{C}\right)$ & $11.9 \pm 4.3 *$ & $15.9 \pm 8.3$ \\
\hline $\mathrm{pH}$ & $7.8 \pm 0.1 *$ & $7.6 \pm 0.3$ \\
\hline Conductivity $(\mu \mathrm{S} / \mathrm{cm})$ & $1278 \pm 198 *$ & $665 \pm 86$ \\
\hline Turbidity (after $100 \mu \mathrm{m}$ prefilter) (NTU) & $1.5 \pm 1.3^{* *}$ & $7.9 \pm 4.1$ \\
\hline Ortho phosphate $(\mathrm{mg} / \mathrm{L})$ & $0.17^{* * *}$ & $0.14^{* * *}$ \\
\hline Calcium $(n=10)(\mathrm{mg} / \mathrm{L})$ & $94.0 \pm 12.4$ & $96.2 \pm 9.5$ \\
\hline Sodium $(n=10)[\mathrm{mg} / \mathrm{L}]$ & $116.0 \pm 19.4$ & $37.6 \pm 2.9$ \\
\hline DOC (combustion) (mg/L) & $12.0 \pm 2.5$ & $8.3 \pm 1.0$ \\
\hline DOC (LC-OCD bypass) (mg/L) & $11.9 \pm 2.4$ & $8.4 \pm 1.2$ \\
\hline Hydrophilicity (SEC/bypass) (\%) & $90.0 \pm 5.2$ & $91.1 \pm 4.4$ \\
\hline UV abs. (1/m) 254 nm 254 nm (LC-UVD bypass UV) & $28.2 \pm 4.1$ & $20.9 \pm 4.8$ \\
\hline UV abs. (1/m) $254 \mathrm{~nm} 254 \mathrm{~nm}$ (LC-UVD bypass UV) & $20.9 \pm 4.6$ & $17.1 \pm 4.2$ \\
\hline UV abs. of inorg. colloids (SEC) $(1 / \mathrm{m})$ & $0.3 \pm 0.1$ & $0.3 \pm 0.1$ \\
\hline Biopolymer C (SEC-OCD) $(\mu \mathrm{g} / \mathrm{L})$ & $880 \pm 133$ & $791 \pm 234$ \\
\hline Biopolymer N (SEC-OND) $(\mu \mathrm{g} / \mathrm{L})$ & $186 \pm 35$ & $115 \pm 33$ \\
\hline Biopolymer $\mathrm{C} / \mathrm{N}$ ratio & $4.8 \pm 0.6$ & $6.9 \pm 1.1$ \\
\hline
\end{tabular}

Notes: ${ }^{*}$ additional values $\left(n_{\min }=10\right)$ from Berliner Wasserbetriebe. ${ }^{* *}$ cited from Zheng et al. [29], $n=44 .{ }^{* * *}$ cited from Zheng et al. [24] as ortho phosphate concentration in average. Part of the data are adapted from [30], with copyright permission from Desalination and Water Treatment.

The content of organics in the SE and SW varies. On average, the SE contains 50\% higher DOC than the SW. This is mainly caused by a higher content of humic substances and building blocks (in terms of $\mathrm{UV}_{254}$, Table 2) in the SE. DOC in the SE shows also higher hydrophobicity than that in the SW (Table 2). As shown, roughly $90 \%$ of the SE DOC can pass through the LC column, while that value increased to $91 \%$ when the SW was measured. The difference seems very minor. However, it is a statistically reliable signal indicating that the EfOM in the SE is more retained by the LC material [25] than the organics in the SW. This is consistent with the higher content of humic-like substances in the SE than in the SW (in terms of $\mathrm{UV}_{254}$ ) while in all DOC fractions these materials are of the highest hydrophobicity [2].

F-EEM confirms certain water characteristics qualified by other methods. As shown in Figure 1, both water samples have peaks at excitation/emission (EX/EM) range of 250/440 nm and 310/400-430 $\mathrm{nm}$ indicating the presence of humic-like substances [26]. The SE sample presents a higher signal intensity at these peaks than the SW sample, which is consistent with the higher humic content quantified by $\mathrm{UV}_{254}$ measurements (Table 2). The SE also shows a higher intensity at the protein-like peak $(270 / 350 \mathrm{~nm})$ than the SW sample presents, indicating it is more significantly affected by microbiological activities in wastewater treatment processes [26]. 

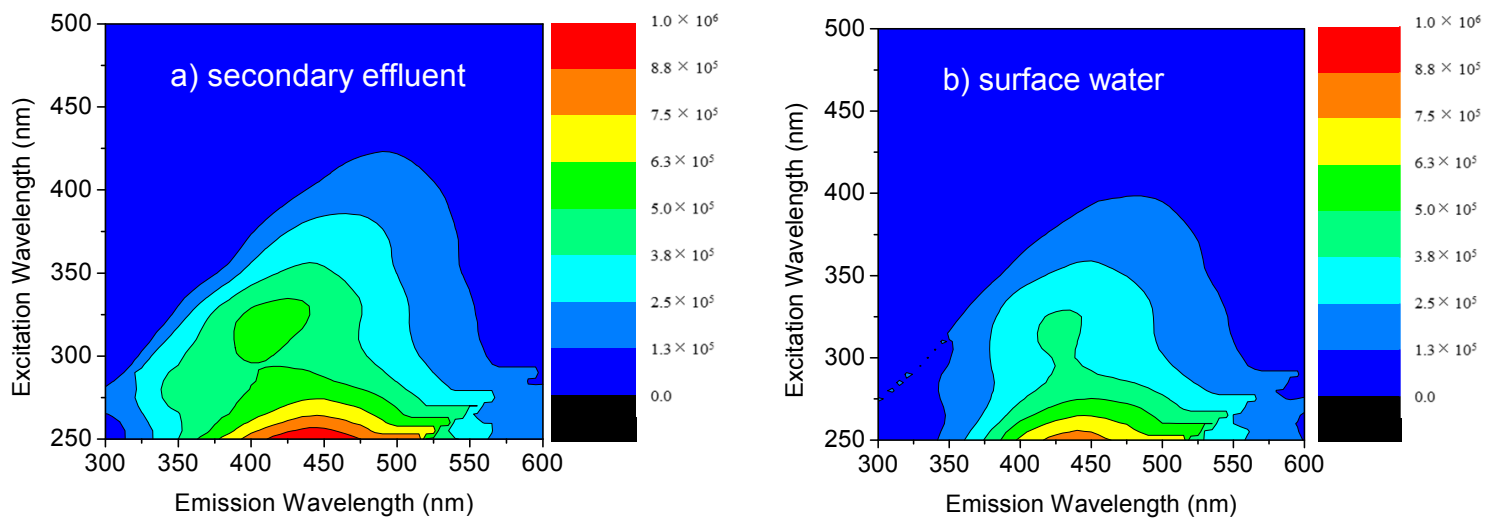

Figure 1. Fluorescence excitation emission matrix (F-EEM) of secondary effluent and surface water.

\subsection{Biopolymers in SE and SW}

Detailed comparison of the molecular size distribution of the organics in both kinds of water is show in Figure 2. It can be seen that the SE and SW contain some biopolymers (elution time 40-60 min). Most of the DOC is contributed from humics and building blocks (elution time 60-80 min). The organics with smaller molecular sizes (elution time after $80 \mathrm{~min}$ ) have limited contribution to DOC. After UF, most of the biopolymers, which are regarded as the major foulants to UF, can be removed (data not shown). Similar phenomena have already been reported in a number of studies [24,31]. The organics detected after elution time of $60 \mathrm{~min}$ are counted as minor foulants because their contribution to hydraulic resistance through surface adsorption is limited compared to biopolymers [2], although their presence does alter the surface property of the membrane and may lead to conditioning fouling which affects subsequent fouling processes [32].

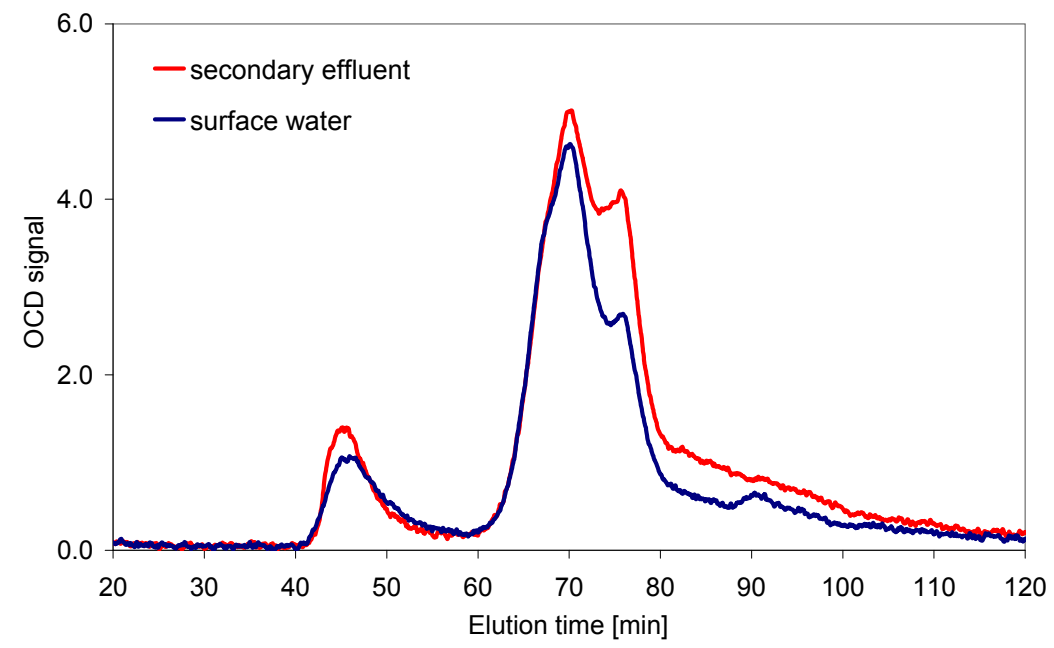

Figure 2. Liquid chromatography with online organic carbon (LC-OCD) chromatograms of secondary effluent and surface water.

Long term water quality monitoring shows that in both types of water the concentration of biopolymers changes seasonally (Figure 3). In the SE, their concentration increased from August to December and decreased when the winter passed. This trend confirms the phenomenon reported in a previous study [24]. Although detailed reason has not been explored thoroughly, several factors such as temperature shock, availability of food and nutrients can affect the living condition of bacteria, and thus the secretion of SMP $[7,8,33]$. Under such challenging conditions, bacteria alter the production of SMP and/or EPS to adapt to the situation and protect their metabolism process [8]. Difference to 
the trend in the SE, biopolymer content in the SW decreased from summer to winter and presented its maximum values at around $1.2 \mathrm{mg} / \mathrm{L}$ in August to September 2010 (Figure 3). In winter, the concentration was about $0.2 \mathrm{mg} / \mathrm{L}$, which is much lower than that in other seasons. As biopolymers in SW originate mainly from algae, detritus and aquatic plant phytoplankton, bacteria, and oysters due to the release of exopolymers, their living conditions such as temperature change affect the quantity and quality of the biopolymers to a large extent [34].
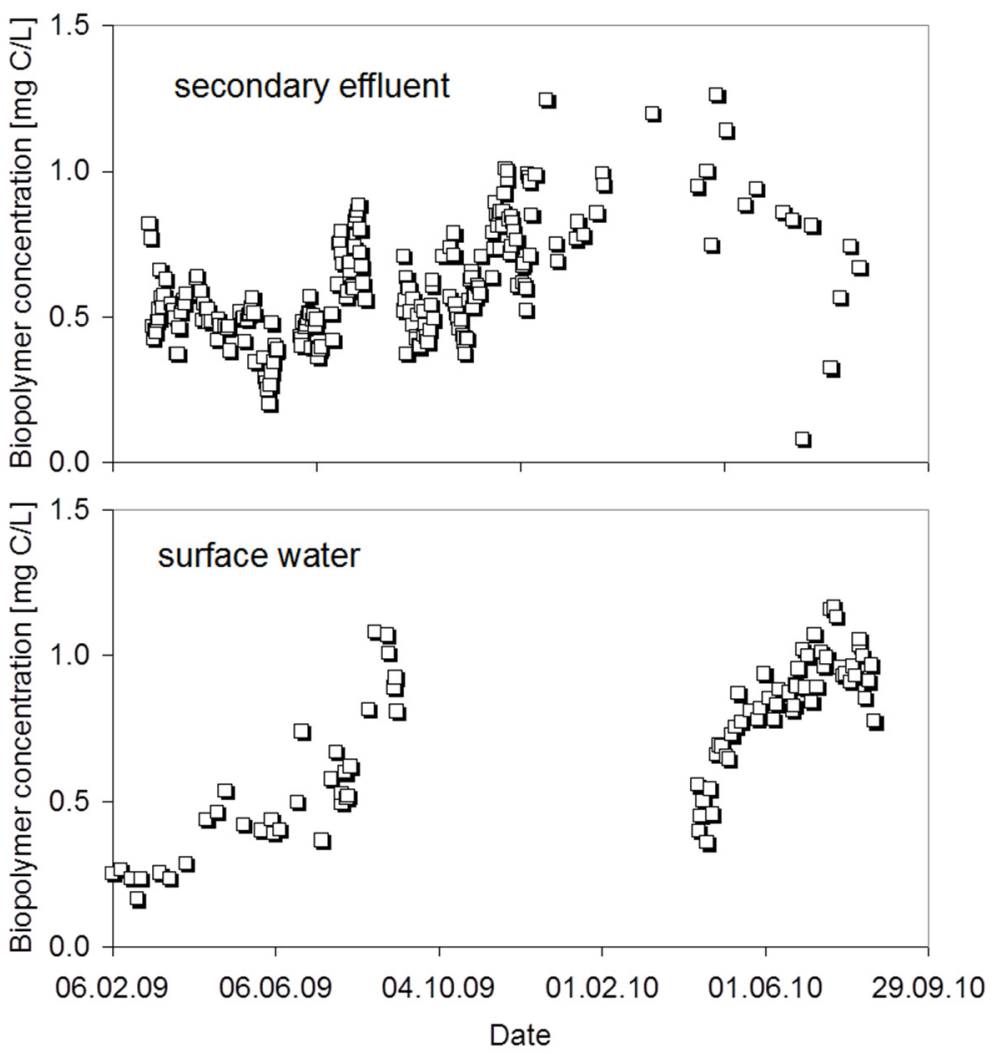

Figure 3. Variation of biopolymer concentration in secondary effluent and surface water (no SW sample was analyzed from October 2009 to April 2010, but the drop of biopolymer concentration from September 2009 to April 2010 implies the process took place in real time).

Not only the quantity of biopolymers fluctuates, but their quality changes as well. In the present investigation, the relative content of organic nitrogen in the SE biopolymer fraction is significantly higher than that in the SW macromolecules, with an average C/N ratio of 4.8 and 6.9 for the SE and SW biopolymers, respectively. Suppose the organic nitrogen is mainly from the protein-like substances [25], they contribute to $63 \%$ of biopolymer DOC in the SE samples, while that in the SW their contribution is around $44 \%$. In both kinds of biopolymers, the content of inorganic colloids is low (UV absorbance of inorganic colloids, Table 2), implying the low content of colloidal silica [25].

The extent of fluctuation of $\mathrm{C} / \mathrm{N}$ ratio within the biopolymer fraction of these two types of water is also different. The ratio in the SE is relatively stable at around 4.8 without a clear trend during the whole sampling period (Figure 4), while SW fluctuates much more significantly (Figure 4). It increased from 4 in April and experienced peak values close to 12 in June. Thereafter, it decreased again. The variation does not follow the change of biopolymer concentration record which increased from April continuously and achieved the highest note in August (Figure 3). For a mixed culture of microorganisms, the causes can be attributed to the changes of bacterial activity, a shift in the nature and/or availability of resources, or even the variation of the microorganism community [35-37]. Detailed analysis can be conducted in future studies. 


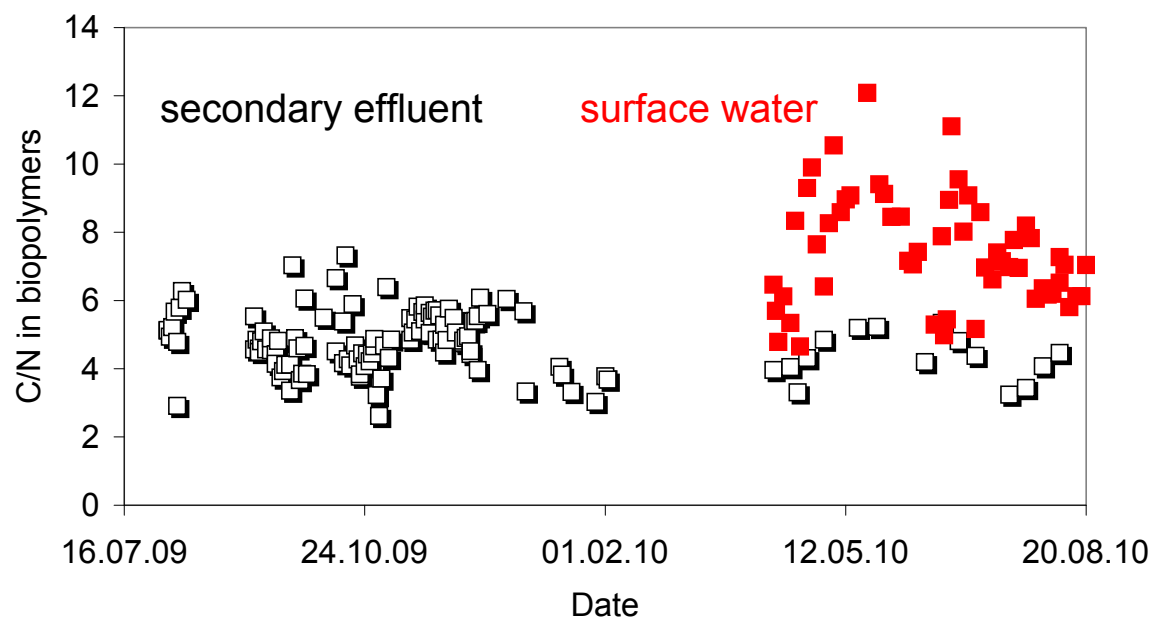

Figure 4. $\mathrm{C} / \mathrm{N}$ ratio within biopolymers in secondary effluent and surface water.

\subsection{Comparison of Filterability and Reversibility in UF}

The quantitative and qualitative change of biopolymer fraction delivers an opportunity to check their corresponding effect on membrane fouling. The comparison of the hydraulic resistance during UF of these two kinds of water shows that under a similar biopolymer load filtering the SE leads to a slightly higher resistance compared to filtering the SW (Figure 5), which is similar to the data presented by Tian et al. [19]. As the resistance is mainly caused by the retention of biopolymers in feed water, which are of similar MW in both feeds (Figure 1), the structure of these organics is supposed to contribute to the difference. Considering that protein-like substances are more abundant in the SE biopolymers, and at a similar MW are denser and of smaller size compared to polysaccharides [38], during filtration, they can present a higher specific resistance than polysaccharides [39,40], thus leading to a slightly higher hydraulic resistance under a similar mass load.
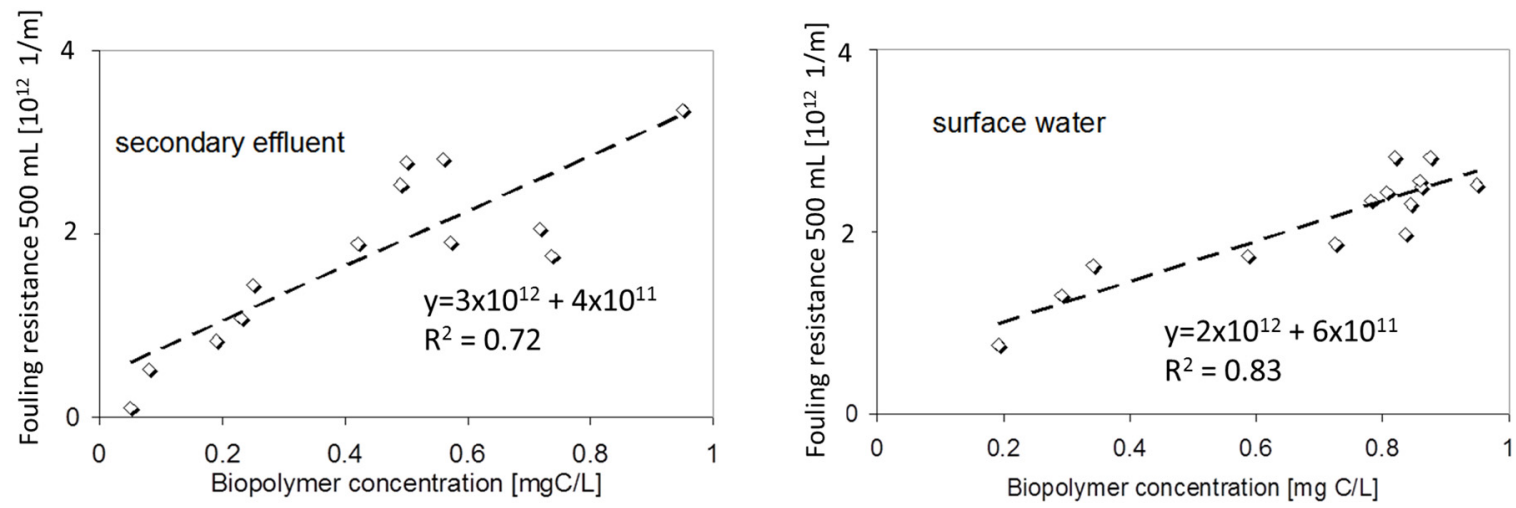

Figure 5. Hydraulic resistance filtering secondary effluent and surface water under $500 \mathrm{~mL}$ permeate volume $(n=13)$.

The reversibility of the fouling formed during UF of both types of water is presented in Figure 6. As shown, a higher biopolymer concentration in the SE leads to more irreversible fouling, which is consistent with the observation in a previous study [24]. There are also studies showing that there is no significant correlation between the biopolymer content and irreversible fouling [11,19]. Being aware that the severity of fouling is related to operational conditions [41] and water chemistry [2], detailed comparison of the experimental condition was conducted. It is shown that in Tian's test demineralized water was used for backwash [19]. This kind of water has been demonstrated to have a much higher removal effect on hydraulically irreversible fouling due to the reduction of $\mathrm{Ca}^{2+}$ bridging effect in the 
organic fouling structure [21]. In the present case back wash water contains a similar concentration of $\mathrm{Ca}^{2+}$ was used as the feed water. Therefore, it is not surprising that the conclusion is different. In another case, cross-flow testing without backwash was applied while operating a bench-scale UF unit [11]. That is different from the dead-end filtration mode with periodic backwash used in the present work. The operational difference leads to uncertain comparisons of the irreversible fouling in these systems, which could be further investigated as a research topic.
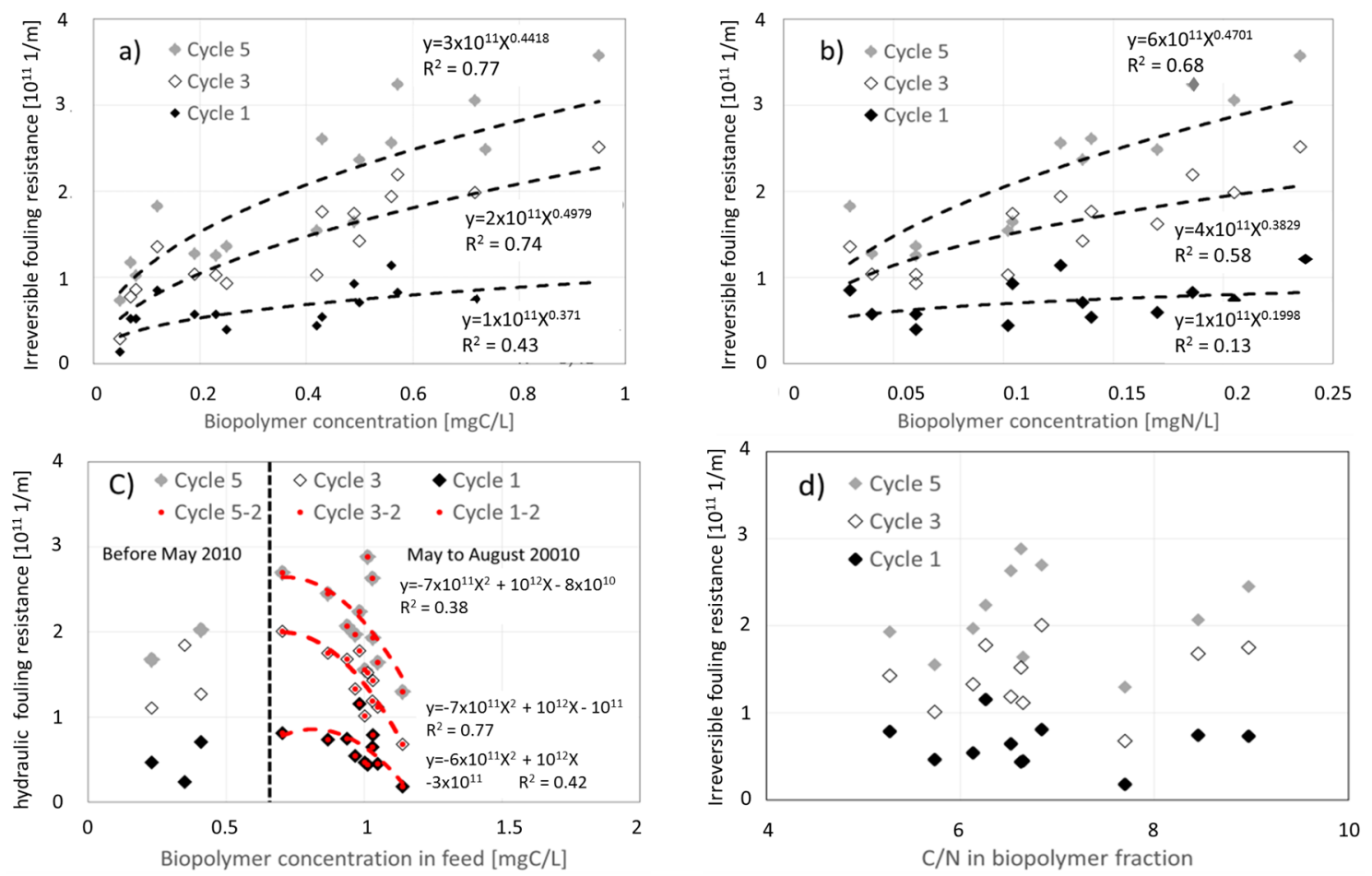

Figure 6. Relationship between irreversible resistance and: (a) organic carbon content of biopolymer in ultrafiltration (UF) of secondary effluent (SE); (b) organic nitrogen content of biopolymer in UF of SE; (c) organic carbon content of biopolymer in UF of surface water (SW); and (d) organic nitrogen content of biopolymer in UF of SW.

The effect of the content of organic nitrogen in biopolymers on irreversible fouling was investigated. Figure $6 \mathrm{~b}$ shows that a higher content of organic nitrogen in the SE biopolymers matches more severe fouling situations, and this trend becomes more apparent with increased number of filtration cycles (Figure 6b). As the ratio of $\mathrm{C} / \mathrm{N}$ is relatively constant in the $\mathrm{SE}$, the relation of both biopolymer carbon and nitrogen content with the severity of fouling exists. When the ratio of $\mathrm{C} / \mathrm{N}$ was plotted against the specific irreversible resistance, no relationship between these two parameters can be established (data not shown). These phenomena imply that polysaccharides and proteins contribute to the irreversible hydraulic resistance together. Their contribution cannot be differentiated under the present experimental conditions.

It is interesting to note that, in Figure 6a,b, correlation between biopolymer concentration and the irreversible fouling resistance can only be found at a later stage of filtration (later than three backwash cycles). Similar phenomena were reported in other studies [41,42], and imply that, during different filtration stages, the mechanisms of forming irreversible fouling are different. It is well argued that during the initial stage of filtration non-selective mono-layer adsorption of both humics and biopolymers occur, which causes the main irreversible fouling (e.g., [41]). Under such condition, no apparent correlation between biopolymer concentration and the irreversible resistance can be observed. In a later stage, however, due to the exhaustion of adsorptive capacity of the membrane, 
the accumulation of biopolymers plays a major role in leading to irreversible resistance. Thus, such relation becomes more apparent [41,42].

In the case of SW, no relationship between the biopolymer content and the irreversible resistance in UF can be found (Figure 6c) when all the samples (from June 2009 to October 2010) are taken into consideration. However, when the data are divided based on the sampling time, a negative correlation between the biopolymer content (sampling from May to August 2010) and the irreversible resistance emerges. Interestingly, increased biopolymer concentration in the feed water is related to decreased irreversible fouling. This result implies that under the current experimental condition a higher amount of SW biopolymers forms a more reversible fouling layer. As the organic nitrogen might be due to the presence of proteins [25], and the increase of relative content of proteins was demonstrated to cause more irreversible fouling $[10,11]$, the correlation between the concentration of nitrogenous biopolymer and membrane fouling was investigated. It is observed that while the organic nitrogen content varied from 0.09 to $0.2 \mathrm{mg} \mathrm{N} / \mathrm{L}$ for these water samples, no correlation between these two parameters can be established.

The result of the SW biopolymer fouling seems to be contradictable to other research results $[4,11]$. These studies found that either the content of the total amount of SW biopolymers or the content of protein-like substances is relevant to the irreversible fouling. Considering Kimura's study, the different conclusion may be due to the application of MF (pore size $0.1 \mu \mathrm{m}$ ) treating different SW. It is evident that MF is more prone to fouling than UF because macromolecules can be more easily pushed into the membrane structure and form irreversible fouling [20]. Variation of the polysaccharide molecular structure during the test period could be another reason. A recent research revealed that even within polysaccharide (alginate) fraction the variation of the ratio between 1,4-linked $\beta$-d-mannuronic acid and $\alpha$-l-guluronic acid will alter the interaction between the organics and the membrane, and thus change the severity of fouling [17]. Although detailed investigation has not been conducted in the present work, the possibility exists while the change of the organic components in the macromolecular fraction is significant (Figures 3 and 4). Further detailed investigation of this topic has begun in our research group.

The reasons for no correlation between organic nitrogen content in biopolymers and the correspondingly formed irreversible fouling can be explored in different perspectives. One cause could be the synergistic effect of mixing proteins and polysaccharides in water. When the organics (e.g., proteins and polysaccharides) are present simultaneously, the final fouling effect is not dependent on one single material, but the interaction between them and with the membrane. For instance, Wang and Tang [12] demonstrated that mixed proteins led to much less fouling compared to when they presented individually. They suggested that the interaction consumes active sites on the molecules when they are mixed together, which reduces the possibility of interacting with the membrane. Similar results can be seen when proteins and polysaccharides are mixed in membrane filtration test [10]. Besides synergistic effect, the exact property and quantity of the organic nitrogen in the biopolymer fraction needs to be addressed. In LC-OCD-OND measurement the organic nitrogen is assumed to be from proteins. However, this has not been quantitatively confirmed because over $40 \%$ of organic components containing nitrogen are not proteins [43]. At this point, further research regarding quantifying the exact content of proteins in the biopolymer fraction needs to be conducted. In addition, the cause could also be due to the fluctuation of water chemistry although sampling conditions were regulated to minimize the influence of precipitation (e.g., variation of conductivity and the concentration of $\mathrm{Ca}^{2+}$ is within $10 \%$, Table 1), fouling-relevant compounds such as Fe was not analyzed. In principle, a multicomponent correlation analysis is required in order to be able to draw definitive conclusions about correlations between fouling and variables. This should be seriously considered in the further research.

\subsection{Fouling Control Using CIP in Pilot Scale Test}

Figure 7 shows the permeability recovery using different chemicals when the pilot UF was fouled after filtering SE and SW. As each test was completed within two days (including filtration and CIP), it 
is assumed that the organic fouling, especially biopolymers, contribute mainly to the overall fouling via gel layer filtration and "gluing" other particles together to the membrane surface [44]. Therefore, CIP test was targeted on cleaning organics. The left side of Figure 7 shows CIP effect of one membrane module after it was fouled in filtering the SE. In general, the fouling in UF can be largely removed using sodium hydroxide at $\mathrm{pH} 12$. This is consistent with other studies that $\mathrm{NaOH}$ is an effective reagent removing organic foulants through hydrolyzing and making them more solvable [45]. Some LC-OCD analysis was conducted and the results show that most of the fouling removed by $\mathrm{NaOH}$ are solvable biopolymer-like organics, which was shown in a previously published study [46]. After base cleaning, different $\mathrm{CIP}$ chemicals were used to remove the $\mathrm{NaOH}$-resistant foulants. The most effective ones are ethanol (100\%) and sodium lauryl sulfate (SDS, $2 \mathrm{~g} / \mathrm{L}$ at $\mathrm{pH} 12)$.

Ethanol is able to remove organic foulants [47] due to coexisting a polar end, the hydroxyl group and a non-polar end, the ethyl group. It is able to dissolve both polar and non-polar compounds. Increasing the content of water in ethanol decreased the effect of cleaning, implying that the removable organics by ethanol might be hydrophobic in nature and be difficult to be dissolved in pure water. SDS solution has been widely used in CIP to remove hydrophobic foulants in assisting with other chemical reagents [45]. Specifically, the nonpolar tail can react with the hydrophobic organic, with the help of ionized tail they can dissolve the organics into water solution. These results imply the $\mathrm{NaOH}$-resistant foulants in UF of SE could be hydrophobic in nature.

Use of enzymes or $\mathrm{H}_{2} \mathrm{O}_{2}$ (Figure 7) to clean the fouled UF after treating the SE was not a success as the permeability was not further improved after $\mathrm{NaOH}$ cleaning (Figure 7). It is not surprising that the enzymes are not working because these substances can only work on specific proteins under well controlled conditions [45]. The weak performance of $\mathrm{H}_{2} \mathrm{O}_{2}$ confirmed the result from a previous study that $\mathrm{H}_{2} \mathrm{O}_{2}$ cannot remove EfOM foulants in UF due to their low oxidation capacity [46].

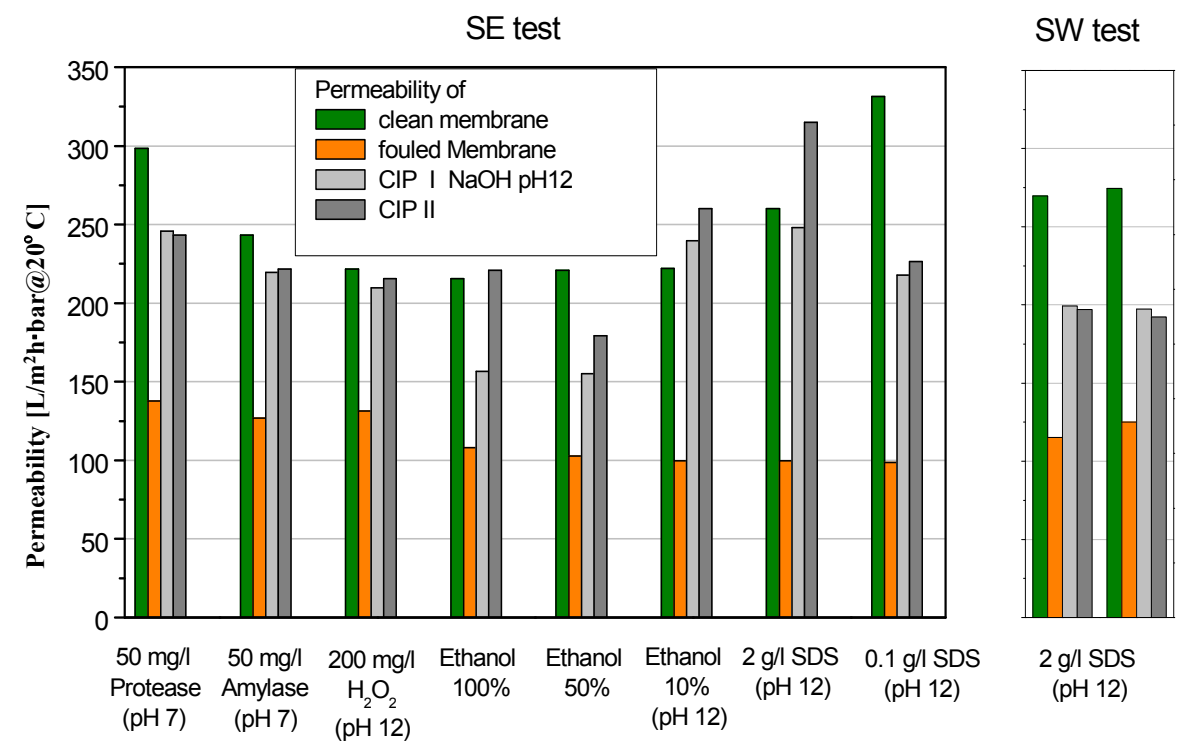

Figure 7. Cleaning effect of UF membrane fouled during filtering secondary effluent and surface water.

The effect using SDS in cleaning EfOM fouling was not observed when it was used to clean the SW fouling. The permeability was even slightly reduced after SDS cleaning (reproducible results on the right side of Figure 7). This result suggests that the irreversible foulants in UF of SW are of significant difference in character compared to that of the EfOM foulant. Considering that EfOM organic is more hydrophobic (Table 2), it can be imagined that in UF of the SE more hydrophobic interaction between foulants and the membrane exists than that during UF of the SW. Therefore, capacity of the surfactant can be fully used in reacting with the EfOM foulants and achieve a promising cleaning effect. Using the same amount of SDS for cleaning SW fouling may cause overdose due to the limited amount of 
hydrophobic foulants on the membrane. The overdosed SDS can even cover the membrane by binding the membrane material instead of the foulants [48,49], and therefore can reduce the permeability of the membrane.

\subsection{Fouling Control Using In-Line Coagulation in Pilot Scale Tests}

Considering the significant difference of these two types of water on turbidity (Table 1), it is challenging to build up the relationship between the biopolymer content in feed water and the performance of the UF pilot, due to the poorly controllable synergistic effect caused by the complicated matrix in the feed. In Tian's work [19] turbidity was demonstrated to have some influence on UF fouling. However, as in-line coagulation can aggregate fine particles ( $>1 \mathrm{um},[50])$, which are the main contributor to turbidity measurement [51], and thus mitigate their influence on fouling, this delivers an opportunity to compare UF performance filtering SE and SW and highlight the fouling difference caused by dissolved fractions.

Figure 8 shows the TMP development of the UF pilot plant filtering SE and SW under different dosage conditions. It is evident that in-line coagulation improves the performance of UF significantly, regardless of the type of feed water. However, dosing similar amount of $\mathrm{FeCl}_{3}$ into the SW achieved a much slower TMP increase rate compared to treating the SE. During the test the biopolymer carbon concentration in the SW fluctuated at around $0.9 \mathrm{mg} \mathrm{C} / \mathrm{L}$ while that in the SE was about $0.6 \mathrm{mg} \mathrm{C} / \mathrm{L}$ on average. In terms of nitrogenous biopolymer concentration, that in the SW was slightly lower than that in the SE, which was 0.10 and $0.11 \mathrm{mg} \mathrm{N} / \mathrm{L}$, respectively (Figure 8).
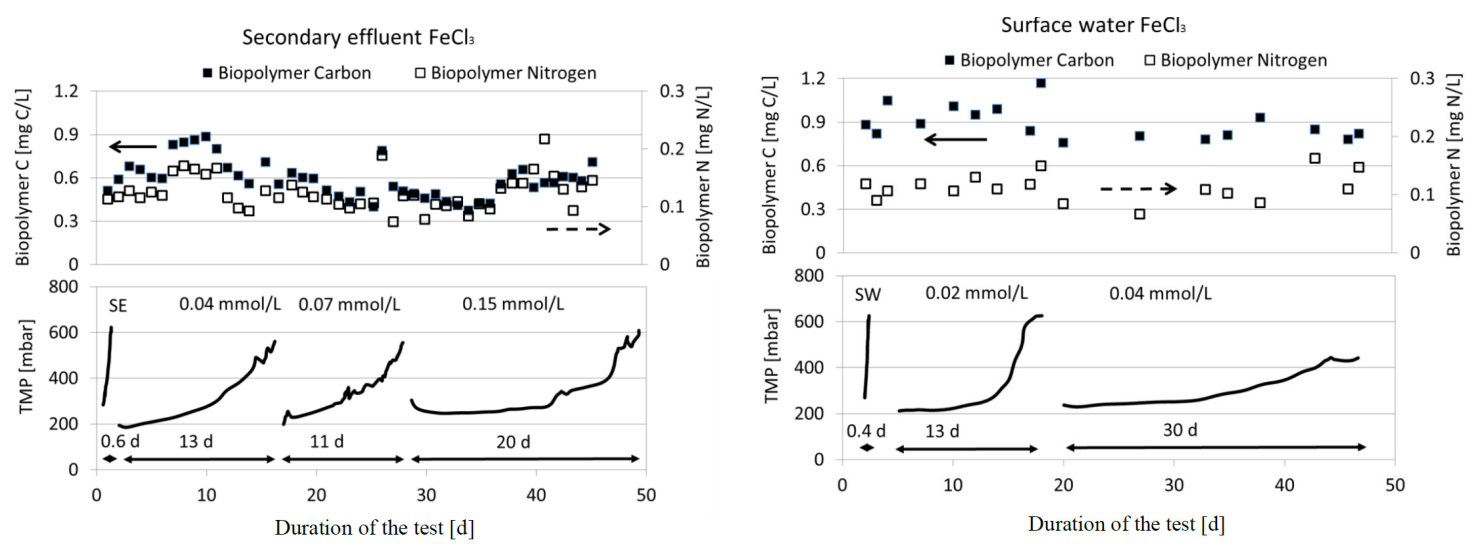

Figure 8. In-line coagulation effect $\left(\mathrm{mmol} \mathrm{Fe}^{3+} / \mathrm{L}\right.$ using $\left.\mathrm{FeCl}_{3}\right)$ in UF of secondary effluent and surface water.

Knowing that not only biopolymer but also humics and phosphorus can consume coagulant [23], the comparison needs to be conducted while considering these factors. In the present work, the SE contains $40 \%$ and $20 \%$ higher humics and orthophosphate respectively than the SW (Table 2). Assuming that the above mentioned water quality difference needs $40 \%$ higher $\mathrm{FeCl}_{3}$ consumption in treating the SE than SW for foulants removal, dosing $0.15 \mathrm{mmol} / \mathrm{L} \mathrm{FeCl}_{3}$ into the SE (the dosage is not overdose [23]) compared to using $0.04 \mathrm{mmol} / \mathrm{L}$ in UF of the SW should result in a slower TMP increase rate. On the contrary, the result was actually the other way around. Figure 8 shows that under such condition the TMP increase rate during UF of the SE is about $20 \mathrm{mbar} / \mathrm{d}$, while that in treating the SW is only $8 \mathrm{mbar} / \mathrm{d}$. It demonstrates clearly that in-line coagulation can control the SW foulants much more effectively than that with the SE foulants. This implies significant difference of the major foulants in nature in these two kinds of water under in-line coagulation condition, which however cannot be represented by biopolymer concentration in the feed, not even in terms of organic carbon or nitrogen content. 


\section{Conclusions}

The present study investigated the character of organic constituents in the range of biopolymer substances in two types of typical water sources, and compared their fouling behavior and controlling effects during the UF process. According to the above-presented results, the following conclusions can be made.

The organics in the investigated secondary effluent and surface water are of similar size distribution pattern. With respect to the biopolymer fraction, the secondary effluent macromolecules contain more protein-like substances than the surface water biopolymers, evidenced by a lower $\mathrm{C} / \mathrm{N}$ ratio compared to that from surface water biopolymers.

Under the conditions applied in the present work, the secondary effluent biopolymer demonstrated a higher fouling potential than that of the investigated surface water samples in general. However, the content of nitrogenous biopolymer cannot be used as a generic indicator representing the fouling potential of different water types due to the lack of quantitatively reliable relation with fouling severity.

The concentration and component of biopolymers in the investigated waters varies seasonally. While that in the secondary effluent increases from summer to winter and reaches a maximum in the cold season, biopolymer content in the present surface water decreases during the same period and achieves the lowest value in winter. Compared to a relatively stable $\mathrm{C} / \mathrm{N}$ ratio in the secondary effluent biopolymer fraction, the ratio in the surface water fluctuates significantly, increasing to a maximum in summer and decreasing afterwards.

$\mathrm{NaOH}$ and sodium lauryl sulfate ( $\mathrm{g} / \mathrm{L}$ at $\mathrm{pH} 12)$ have been shown as effective chemical cleaning reagents recovering the permeability of a UF membrane after filtering the secondary effluent. Sodium lauryl sulfate shows no effect in cleaning UF membranes fouled by the investigated surface water organics, implying that the foulants in the surface water may have higher hydrophilicity compared to that in the secondary effluent.

In-line coagulation using $\mathrm{FeCl}_{3}$ is demonstrated to be an effective procedure controlling fouling in UF of secondary effluent and surface water. Under comparable biopolymer concentrations in the feed water, in-line coagulation is more effective in controlling fouling in UF of the surface water than treating the secondary effluent.

Acknowledgments: The investigations and preparation of the article were conducted within the research project "Sustainable water concept and its application for the Olympic Games 2008-Phase II" (02 WA 1016) supported by Federal Ministry of Education and Research (BMBF, Germany) and State Key Laboratory Base of Eco-Hydraulic Engineering in Arid Area (104-438016024) which are highly acknowledged.

Author Contributions: Xing Zheng and Martin Jekel conceived and designed the experiments; Frederik Zietzschmann, Stephan Plume and Hendrik Paar performed the experiments; Xing Zheng, Mathias Ernst and Martin Jekel analyzed the data; Xing Zheng, Frederik Zietzschmann, Stephan Plume and Hendrik Paar contributed reagents/materials/analysis tools; and Xing Zheng, Zi Wang and Mathias Ernst wrote the paper.

Conflicts of Interest: The authors declare no conflict of interest.

\section{References}

1. Amy, G. Fundamental understanding of organic matter fouling of membranes. Desalination 2008, $231,44-51$. [CrossRef]

2. Zheng, X.; Khan, M.T.; Croué, J.P. Contribution of effluent organic matter (EfOM) to ultrafiltration (UF) membrane fouling: Isolation, characterization, and fouling effect of EfOM fractions. Water Res. 2014, 65, 414-424. [CrossRef] [PubMed]

3. Myat, D.T.; Stewart, M.B.; Mergen, M.; Zhao, O.; Orbell, J.D.; Gray, S. Experimental and computational investigations of the interactions between model organic compounds and subsequent membrane fouling. Water Res. 2014, 48, 108-118. [CrossRef] [PubMed] 
4. Kimura, K.; Tanaka, K.; Watanabe, Y. Microfiltration of different surface waters with/without coagulation: Clear correlations between membrane fouling and hydrophilic biopolymers. Water Res. 2014, 49, 434-443. [CrossRef] [PubMed]

5. Hallé, C.; Huck, P.M.; Peldszus, S.; Haberkamp, J.; Jekel, M. Assessing the performance of biological filtration as pretreatment to low pressure membranes for drinking water. Environ. Sci. Technol. 2009, 43, 3878-3884. [PubMed]

6. Jiang, T.; Kennedy, M.D.; Schepper, V.D.; Nam, S.N.; Nopens, I.; Vanrolleghem, P.A.; Amy, G. Characterization of soluble microbial products and their fouling impacts in membrane bioreactors. Environ. Sci. Technol. 2010, 44, 6642-6648. [CrossRef] [PubMed]

7. Song, G.; Wang, J.; Chiu, C.A.; Westerhoff, P. Biogenic nanoscale colloids in wastewater effluents. Environ. Sci. Technol. 2010, 44, 8216-8222. [CrossRef] [PubMed]

8. Ni, B.J.; Rittmann, B.E.; Yu, H.Q. Soluble microbial products and their implications in mixed culture biotechnology. Trends Biotechnol. 2011, 29, 454-463. [CrossRef] [PubMed]

9. Contreras, A.E.; Steiner, Z.; Miao, J.; Kasher, R.; Li, Q. Studying the role of common membrane surface functionalities on adsorption and cleaning of organic foulants using QCM-D. Environ. Sci. Technol. 2011, 45, 6309-6315. [CrossRef] [PubMed]

10. Jermann, D.; Pronk, W.; Meylan, S.; Boller, M. Interplay of different NOM fouling mechanisms during ultrafiltration for drinking water production. Water Res. 2007, 41, 1713-1722. [CrossRef] [PubMed]

11. Haberkamp, J.; Ernst, M.; Böckelmann, U.; Szewzyk, U.; Jekel, M. Complexity of ultrafiltration membrane fouling caused by macromolecular dissolved organic compounds in secondary effluents. Water Res. 2008, 42, 3153-3161. [CrossRef] [PubMed]

12. Wang, Y.N.; Tang, C.Y. Fouling of nanofiltration, reverse osmosis, and ultrafiltration membranes by protein mixtures: The role of inter-foulant-species interaction. Environ. Sci. Technol. 2011, 45, 6373-6379. [CrossRef] [PubMed]

13. Kim, H.C.; Dempsey, B.A. Membrane fouling due to alginate, SMP, EfOM, humic acid, and NOM. J. Membr. Sci. 2013, 428, 190-197. [CrossRef]

14. Leenheer, J.A. Systematic Approaches to Comprehensive Analyses of Natural Organic Matter. Ann. Environ. Sci. 2009, 3, 1-130.

15. Passow, U.; Shipe, R.F.; Murray, A.; Pak, D.K.; Brzezinski, M.A.; Alldredge, A.L. The origin of transparent exopolymer particles (TEP) and their role in the sedimentation of particulate matter. Cont. Shelf Res. 2001, 21, 327-346. [CrossRef]

16. Passow, U. Transparent exopolymer particles (TEP) in aquatic environments. Prog. Oceanogr. 2002, 55, 287-333. [CrossRef]

17. Meng, S.; Liu, Y. Alginate block fractions and their effects on membrane fouling. Water Res. 2013, 47, 6618-6627. [CrossRef] [PubMed]

18. Susanto, H.; Arafat, H.; Janssen, E.M.L.; Ulbricht, M. Ultrafiltration of polysaccharide-protein mixtures: Elucidation of fouling mechanisms and fouling control by membrane surface modification. Sep. Purif. Technol. 2008, 63, 558-565. [CrossRef]

19. Tian, J.Y.; Ernst, M.; Cui, F.; Jekel, M. Correlations of relevant membrane foulants with UF membrane fouling in different waters. Water Res. 2013, 47, 1218-1228. [CrossRef] [PubMed]

20. Huang, H.; Lee, N.; Young, T.; Gary, A.; Lozier, J.C.; Jacangelo, J.G. Natural organic matter fouling of low-pressure, hollow-fiber membranes: Effects of NOM source and hydrodynamic conditions. Water Res. 2007, 41, 3823-3832. [CrossRef] [PubMed]

21. Li, S.; Heijman, S.G.J.; Verberk, J.Q.J.C.; Le Clech, P.; Lu, J.; Kemperman, A.J.B.; Amy, G.L.; van Dijk, J.C. Fouling control mechanisms of demineralized water backwash: Reduction of charge screening and calcium bridging effects. Water Res. 2011, 45, 6289-6300. [CrossRef] [PubMed]

22. Nguyen, A.H.; Tobiason, J.E.; Howe, K.J. Fouling indices for low pressure hollow fiber membrane performance assessment. Water Res. 2011, 45, 2627-2637. [CrossRef] [PubMed]

23. Zheng, X.; Plume, S.; Ernst, M.; Croué, J.P.; Jekel, M. In-line coagulation prior to UF of treated domestic wastewater-foulants removal, fouling control and phosphorus removal. J. Membr. Sci. 2012, 129-139. [CrossRef]

24. Zheng, X.; Ernst, M.; Huck, P.M.; Jekel, M. Biopolymer fouling in dead-end ultrafiltration of treated domestic wastewater. Water Res. 2010, 44, 5212-5221. [CrossRef] [PubMed] 
25. Huber, S.A.; Balz, A.; Abert, M.; Pronk, W. Characterisation of aquatic humic and non-humic matter with size-exclusion chromatography-organic carbon detection-organic nitrogen detection (LC-OCD-OND). Water Res. 2011, 45, 879-885. [CrossRef] [PubMed]

26. Henderson, R.K.; Baker, A.; Murphy, K.R.; Hambly, A.; Stuetz, R.M.; Khan, S.J. Fluorescence as a potential monitoring tool for recycled water systems: A review. Water Res. 2009, 43, 863-881. [CrossRef] [PubMed]

27. Van den Brink, P.; Zwijnenburg, A.; Smith, G.; Temmink, H.; van Loosdrecht, M. Effect of free calcium concentration and ionic strength on alginate fouling in cross-flow membrane filtration. J. Membr. Sci. 2009, 345, 207-216. [CrossRef]

28. Koo, C.H.; Mohammad, A.W.; Suja, F.; Meor Talib, M.Z. Review of the effect of selected physicochemical factors on membrane fouling propensity based on fouling indices. Desalination 2012, 287, 167-177. [CrossRef]

29. Zheng, X.; Ernst, M.; Jekel, M. Pilot-scale investigation on the removal of organic foulants in secondary effluent by slow sand filtration prior to ultrafiltration. Water Res. 2010, 44, 3203-3213. [CrossRef] [PubMed]

30. Zietzschmann, F.; Ernst, M.; Godehardt, M.; Paar, H.; Zheng, X.; Jekel, M. Linking UF reversible and irreversible fouling to the water quality of surface water and treated municipal wastewater. Desalin. Water Treat. 2014, 52, 7598-7608.

31. Peiris, R.H.; Hallé, C.; Budman, H.; Moresoli, C.; Peldszus, S.; Huck, P.M.; Legge, R.L. Identifying fouling events in a membrane-based drinking water treatment process using principal component analysis of fluorescence excitation-emission matrices. Water Res. 2010, 44, 185-194. [CrossRef] [PubMed]

32. Xiao, K.; Wang, X.M.; Huang, X.; Waite, T.D.; Wen, X.H. Analysis of polysaccharides, protein and humic acid retention by microfiltration membranes using Thomas' dynamic adsorption model. J. Membr. Sci. 2009, 342, 22-34. [CrossRef]

33. Barker, D.J.; Stuckey, D.C. A review of soluble microbial products (SMP) in wastewater treatment systems. Water Res. 1999, 33, 3063-3082. [CrossRef]

34. Heinonen, K.B.; Ward, J.E.; Holohan, B.A. Production of transparent exopolymer particles (TEP) by benthic suspension feeders in coastal systems. J. Exp. Mar. Biol. Ecol. 2007, 341, 184-195. [CrossRef]

35. Chrzanowski, T.H.; Kyle, M.; Elser, J.J.; Sterner, R.W. Element ratios and growth dynamics of bacteria in an oligotrophic Canadian shield lake. Aquat. Microb. Ecol. 1996, 11, 119-125. [CrossRef]

36. Westerhoff, P.; Rodriguez-Hernandez, M.; Baker, L.; Sommerfeld, M. Seasonal occurrence and degradation of 2-methylisoborneol in water supply reservoirs. Water Res. 2005, 39, 4899-4912. [CrossRef] [PubMed]

37. Vrede, K.; Heldal, M.; Norland, S.; Bratbak, G. Elemental composition (C, N, P) and cell volume of exponentially growing and nutrient-limited bacterioplankton. Appl. Environ. Microbiol. 2002, 68, $2965-2971$. [CrossRef] [PubMed]

38. Haberkamp, J. Organic membrane fouling in ultrafiltration of treated domestic wastewater: Causes, mechanisms and methods to reduce. Ph.D. Thesis, Technical University of Berlin, Berlin, German, 2008.

39. Ho, C.C.; Zydney, A.L. Protein fouling of asymmetric and composite microfiltration membranes. Ind. Eng. Chem. Res. 2001, 40, 1412-1421. [CrossRef]

40. Ye, Y.; Le Clech, P.; Chen, V.; Fane, A.G. Evolution of fouling during crossflow filtration of model EPS solutions. J. Membr. Sci. 2005, 264, 190-199. [CrossRef]

41. Shang, R.; Vuong, F.; Hu, J.Y.; Li, S.; Kemperman, A.J.B.; Nijmeijer, K.; Cornelissen, E.R.; Heijman, S.G.J.; Rietveld, L.C. Hydraulically irreversible fouling on ceramic MF/UF membranes: Comparison of fouling indices, foulant composition and irreversible pore narrowing. Sep. Purif. Technol. 2015, 147, 303-310.

42. Yangali-Quintanilla, V.A.; Holm, A.H.; Birkner, M.; D’Antonio, S.; Stoltze, H.W.C.; Ulbricht, M.; Zheng, X. A fast and reliable approach to benchmark low pressure hollow fibre filtration membranes for water purification. J. Membr. Sci. 2016, 499, 515-525. [CrossRef]

43. Westgate, P.J.; Park, C. Evaluation of proteins and organic nitrogen in wastewater treatment effluents. Environ. Sci. Technol. 2010, 44, 5352-5357. [CrossRef] [PubMed]

44. Wang, X.M.; Waite, T.D. Gel layer formation and hollow fiber membrane filterability of polysaccharide dispersions. J. Membr. Sci. 2008, 322, 204-213. [CrossRef]

45. Regula, C.; Carretier, E.; Wyart, Y.; Gésan-Guiziou, G.; Vincent, A.; Boudot, D.; Moulin, P. Chemical cleaning/disinfection and ageing of organic UF membranes: A review. Water Res. 2014, 56, 325-365. [CrossRef] [PubMed]

46. Zheng, X.; Ernst, M.; Jekel, M. Stabilizing the performance of ultrafiltration in filtering tertiary effluent-Technical choices and economic comparisons. J. Membr. Sci. 2011, 366, 82-91. [CrossRef] 
47. Tian, J.Y.; Chen, Z.L.; Yang, Y.L.; Liang, H.; Nan, J.; Li, G.B. Consecutive chemical cleaning of fouled PVC membrane using $\mathrm{NaOH}$ and ethanol during ultrafiltration of river water. Water Res. 2010, 44, 59-68. [CrossRef] [PubMed]

48. Kingma, A.J. Compatibility of nonionic surfactants with membrane materials and their cleaning performance. Food Bioprod. Process. 2015, 93, 304-309. [CrossRef]

49. Chen, P.; Zhong, Z.; Liu, F.; Xing, W. Cleaning ceramic membranes used in treating desizing wastewater with a complex-surfactant SDBS-assisted method. Desalination 2015, 365, 25-35. [CrossRef]

50. Pearce, G.K. UF/MF Membrane Water Treatment: Principles and Design; Water Treatment Academy: Bangkok, Thailand, 2011.

51. He, W.P.; Nan, J. Study on the impact of particle size distribution on turbidity in water. Desalin. Water Treat. 2012, 41, 26-34. [CrossRef]

(C) 2017 by the authors. Licensee MDPI, Basel, Switzerland. This article is an open access article distributed under the terms and conditions of the Creative Commons Attribution (CC BY) license (http:/ / creativecommons.org/licenses/by/4.0/). 